\author{
Амитришин Володимир Степанович, \\ КанАиАат юриАичних наук, Аоцент, \\ старший науковий співробітник \\ наукового відділу організації медичної допомоги \\ Аержавної наукової установи \\ «Науково-практичний центр профілактичної \\ та клінічної меАицини" Аержавного управління справами
}

\title{
НАБУТТЯ ТА РОЗПОРЯДЖАННЯ МАЙНОВИМИ ПРАВАМИ ІНТЕЛЕКТУАЛЬНОЇ ВЛАСНОСТІ ФІЗИЧНИМИ ОСОБАМИ - ПІДПРИЕМЦЯМИ
}

Постановка проблеми. Законодавством України, зокрема статтею 51 Цивільного кодексу [1], передбачено, що Ао піАприємницької Аіяльності фізичних осіб застосовуються нормативно-правові акти, що регулюють піАприємницьку Аіяльність юриАичних осіб, якщо інше не встановлено законом або не випливає із суті відносин. Проте не зовсім однозначне тлумачення зазначеної норми в науково-юридичній літературі та у практиці правозастосування зумовлює появу суперечливих висновків, оскільки певним чином відбувається злиття правового статусу фізичної особи з правовим статусом юридичної особи, які за своєю правовою природою є різними. ПіА час правозастосування виникають ситуації, коли необхідно чітко розмежовувати фізичну особу як таку та фізичну особу - суб'єкта піАприємницької Аіяльності, що суттєво впливає на обсяг прав та обов'язків особи, механізми реалізації цих прав та виконання обов'язків, наслідки дій особи.

ОАним із таких випадків $€$ випадок набуття Аержавної реєстрації та розпоряАжання майновими правами інтелектуальної власності. Зокрема, виникають питання в процесі реєстрації авторського права, невизначеності щодо належності прав на твір, створений у порядку виконання службового завАання, різні тлумачення щодо суб'єктності сторін у процесі уклаАання Аоговорів про передання майнових прав та ліцензійних Аоговорів на об'єкти інтелектуальної власності. Чи має, наприклаА, фізична особа, яка є автором об'єкта інтелектуальної власності, уклаАати Аоговори із собою як фізичною особою - піАприєм- цем, Аоговір про передання прав на такий об'єкт, якщо вона має намір реалізувати своє право на розпоряАжання цим об'єктом як піАприємець або використовувати його саме у своїй піАприємницькій Аіяльності? Розгляду зазначених питань присвячена ця стаття.

Стан АосліАження теми. Необхідно зазначити, що питанням, пов'язаним із Аіяльністю фізичних осіб - піАприємців, наразі більше уваги приділяють органи, що зАійснюють правозастосування, ніж наукова спільнота. Ці питання освітлюються в мистах Аержавної фіскальної служби, судових рішеннях, Аокументах Міністерства юстиції України. 3 наукової точки зору питання правосуб'єктності фізичних осіб - суб'єктів піАприємницької Аіяльності розгляАали такі науковці, як О. Яра, І. Бутков, Р. Майданник, О. Аем'яненко та інші. Що стосується питань розпоряАжання майновими правами інтелектуальної власності, то можна визначити роботи із цього питання таких авторів, як О. Тверезенко, Б. Шапіро, В. Аозорцев, Г. Штумп стосується питання Аоговірного розпоряАжання правами інтелектуальної власності саме фізичних осіб - суб'єктів піАприємницької Аіяльності та віАношення використання таких об'єктів саме в піАприємницькій Аіяльності зазначеного суб'єкта, то з наукової точки зору воно залишається малоАосліАженим.

Метою стапті $\epsilon$ Аослідження правових механізмів набуття, розпорядження і використання в господарській Аіяльності фізичними особами піАприємцями об'єктів інтелектуальної власності, 
співвідношення правового статусу таких осіб та статусу фізичних осіб - авторів таких об'єктів і вплив їх правового статусу на правовіАносини щодо прав інтелектуальної власності.

ВикиаА основного матеріалу АосліАження. Чинне законодавство України передбачає можливість специфічної форми ведення піАприємницької Аіяльності - фізична особа - підприємець. Зокрема, стаття 50 Цивільного кодексу України [1] встановлює, що фізична особа з повною цивільною Аієздатністю має право на зАійснення підприємницької Аіяльності, яку не заборонено законом та зАійснює своє право на підприємницьку Аіяльність за умови ії державної реєстрації в порядку, встановленому законом. Стаття 128 Господарського кодексу України [2] визначає, що громадянин визнається суб'єктом господарювання в разі зАійснення ним підприємницької Аіяльності за умови державної реєстрації його як підприємця без статусу юридичної особи та може зАійснювати підприємницьку Аіяльність безпосередньо як підприємець або через приватне підприємство, що ним створюється.

Зазначені положення законодавства Аозволяють реалізовувати право громадянина на піАприємницьку Аіяльність, створюють економічне підґрунтя Аля залучення активної частини населення Ао економічних процесів у Аержаві та $є$ позитивним соціальним чинником суспільного розвитку країни.

Стаття 2 Цивільного кодексу України визначає учасниками цивільних віАносин фізичних та юриАичних осіб. Фізичні особи - піАприємці, які зага^ом теж охоплюються поняттям "фізичні особи", зазначеною нормою залишаються фактично поза правовим регулюванням у цивільних віАносинах через певні віАмінності у їх правовому статусі. При цьому необхінно зазначити, що правовий статус фізичної особи є значно об'ємнішим, ніж правовий статус фізичної особи - піАприємця. Через це питання про місце у сфері правовідносин у галузі інтелектуальної власності фізичних осіб - підприємців, правове регулювання, яке має застосовуватись до таких відносин, не опрацьоване в юриАичній науці і залишається віАкритим.

Як віАомо, базовим посилом Аля розгляАу цього питання $€$ те, що право інтелектуальної власності $\epsilon$ приватним правом. Його первинним носієм може бути мише фізична особа, творець такого об'єкта, інтелектуальною працею якого створено такий об'єкт. Саме акт творчості ^юдини є визначальним Аля віднесення створеного об'єкта Ао об'єктів інтелектуальної власності. Зазначені аксі- оматичні положення знайшли своє відображення і у формальних нормах права. Зокрема, це піАкреслено тим, що положення про права інтелектуальної власності розміщенні в Розділі II «Права, свободи та обов' язки АюАини і громадянина» Конституції України. Стаття 41 цього Розділу встанов^ює, що кожен має право володіти, користуватися і розпоряджатися своєю власністю, результатами своєї інтелектуальної, творчої Аіяльності. Стаття 54 підкреслює, що громадянам гарантується свобода мітературної, художньої, наукової і технічної творчості, захист інтелектуальної власності, їхніх авторських прав, моральних і матеріальних інтересів, що виникають у зв'язку з різними видами інтелектуальної Аіяльності. Кожний громаАянин має право на результати своєї інтелектуальної, творчої діяльності; ніхто не може використовувати або поширювати їх без його згоди, за винятками, встановленими законом. Як ми бачимо, мова йде саме про громаАян, тобто про фізичних осіб, ^юдей, творців таких об'єктів [3].

Зазначені положення Конституції України знайшли своє продовження та розвиток і в чинному законодавств України. Так, стаття 435 Цивільного Кодексу України, кажучи про суб'єктів авторського права, визначає, що первинним суб'єктом авторського права $€$ автор твору. За відсутності Аоказів іншого автором твору вважається фізична особа, зазначена звичайним способом як автор на оригіналі або примірнику твору (презумпція авторства). Мова, як ми бачимо, йде саме про фізичну особу - автора.

Стаття 1 Закону України «Про авторське право і суміжні права" визначає, що автор - це фізична особа, яка своєю творчою працею створила твір [4]. Відповідно до статті 1 Закону України "Про охорону прав на винаходи і корисні моделі" винахіА (корисна модель) - результат інтелектуальної Аіяльності ^юАини в будь-якій сфері технології, а винахіАник - ^юАина, інтелектуальною, творчою Аіяльністю якої створено винахіА (корисну модель) [5].

ОАнак стаття 418 ЦК визначає, що право інтелектуальної власності - це право особи на результат інтелектуальної, творчої діяльності або на інший об'єкт права інтелектуальної власності. Мова йде саме про особу, безвідносно Ао того, юридична чи фізична особа є такою. Стаття ж 421 зазначає, що суб'єктами права інтелектуальної власності є: творець (творці) об'єкта права інтелектуальної власності (автор, виконавець, винахідник тощо) та інші особи, яким належать особисті немайнові та (або) майнові права 


\section{0 回回回回回回回回回回回回回回回回回回回回 Випуск 33}

інтелектуальної власності відповіАно до цього Кодексу, іншого закону чи договору.

Правова позиція Аержавної фіскальної служба України із цього питання полягає в тому, що суб'єктом права власності законодавством визначається фізична особа, яка може бути власником будь-якого майна, крім майна, яке не може перебувати у власності фізичної особи. Такий суб'єкт права власності як фізична особа - підприємець чинним законодавством не визначено. Оскільки фізична особа - підприємець не може бути власником нерухомого або рухомого майна, приАбання такого майна та операції з передачі права власності на таке майно фізичною особою - піАприємцем можуть зАійснюватися лише як фізичною особою [6].

Верховний Суа у складі судової палати Аля розгляАу справ щодо податків, зборів та інших обов'язкових платежів Касаційного аАміністративного суАу також висловив свою Аумку із цього питання, зокрема зазначивши, що "фізична особа-підприємець" та "фізична особа" мають різний податковий та правовий статус. Податковий орган, який є стороною у справі, зазначає, що може бути приватною власністю мише фізичної або юридичної особи та в подальшому використовуватись на власний розсуд у піАприємницькій Аіяльності. Натомість законодавство України не передбачає можливості вважати майно, яке знаходиться у приватній власності фізичної особи, основними фондами суб'єкта господарювання.

Вирішуючи спір, Суд зазначає, що в такому випалку важливо звернути увагу, що віАповіАно Ао частини першої статті 51 ЦК України Ао піАприємницької Аіяльності фізичних осіб застосовуються нормативно-правові акти, що регулюють піАприємницьку Аіяльність юриАичних осіб, якщо інше не встановлено законом або не випливає із суті відносин. Це положення однаково відноситься Ао прав і Ао обов'язків фізичної особи-піАприємця. I тому важливо встановити фактичні обставини по справі та надані їм правильну правову оцінку з урахуванням наведених вимог податкового законодавства. А важливими обставинами в цьому випадку Суд вважає, насампереА, яку систему оподаткування обрано позивачем, факт реєстрації фізичної особи - підпримця як платника ПАВ та подальше використання таких товарів в оподатковуваних операціях у межах господарської Аіяльності [7].

На Аумку Колегії судаів Аьвівського апеляційного аАміністративного суду у справі за позовом фізичної особи - піАприємця до органів Аержав- ної фіскальної служби у ^ьвівській області, винагорода, отримана фізичною особою - підприємцем за відчуження прав на об'єкт інтелектуальної власності, була саме винагородою фізичної особи як автора цієї програми.

Аане рішення було прийняте у справі, Ае, на Аумку позивача (органи АФС), є необхіАним повторне оподаткування авторської винагороди податком на Аоходи фізичних осіб та безпідставне вик^ючення суми авторської винагороди зі складу Аоходів платника єАиного податку. Як аргумент було зазначено, що юридична особа (фізична особа підприємець) не може бути автором твору, тому що твір створюється тільки творчою працею фізичної особи, її (ФОП) права є вторинними (похідними). Юридична особа може створювати організаційні, матеріальні умови Аля творчої праці ^юАини, але сама не може були автором. А також передача майнових прав автора оформ^яється авторським договором, у якому зазначаються майнові права, що передаються за авторським Аоговором. Також, на Аумку АФС, ФОП, як фізична особа, набув авторських прав піА час здійснення господарської діяльності в якості фізичної особи - піАприємця, та в подальшому відчужуючи майнові права інтелектуальної власності, отримав пасивний дохіА віА такого продажу, оскільки фізична особа - підприємець не набував майнових прав інтелектуальної власності і, віАповіАно, не міг їх реалізовувати.

Колегія судАів стала на сторону піАприємця та зазначила, що позивач $€$ автором у розумінні чинного законодавства та волоАіє Аодатково правовим статусом фізичної особи - піАприємця, зАійснює піАприємницьку Аіяльність, яка в тому числі включала створення об'єктів авторського права. ВіАповіАно Ао п. 297.1 ст. 297 ПК України платники єАиного податку звільняються віА обов'язку нарахування, сплати та подання податкової звітності з податку на доходи фізичних осіб у частині Аоходів (об'єкта оподаткування), що отримані в результаті господарської Аіяльності фізичної особи та оподатковані за спрощеною системою оподаткування, обліку та звітності [8].

В іншій справі Київський окружний аАміністративний суА зазначив таке. ВіАповіАно Ао статті 42 ГК України підприємництво - це самостійна, ініціативна, систематична, на власний ризик господарська Аіяльність, що здійснюється суб'єктами господарювання (підприємцями). Між тим стаття 55 визначає, що суб'єктами госпоАарювання визнаються, зокрема, громадяни 
України, іноземці та особи без громадянства, які зареєстровані відповіАно Ао закону як піАприємці та зАійснюють господарську Аіяльність, реалізуючи господарську компетенцію, мають відокремлене майно і несуть відповідальність за своїми зобов'язаннями в межах цього майна, крім випадків, передбачених законодавством.

Ураховуючи наведене, сліА віАмітити, що чинне законодавство не виділяє такого суб'єкта права власності, як фізична особа - підприємець, та не містить норм щодо права власності фізичної особи - підприємця. Отже, суб'єктом права власності визнається саме фізична особа, яка може бути власником будь-якого майна, крім майна, що не може перебувати у власності фізичної особи. При цьому правовий статус фізичної особи - піАприємця не впливає на правовий режим майна, що перебуває у його власності [9].

Показовим є також рішення Вищого господарського суАу, коли він прийшов Ао висновку: "ПіА час зАійснення господарської Аіяльності фізичні особи - підприємці реалізують свою господарську компетенцію, тобто сукупність господарських прав та обов'язків. При цьому решта прав та обов'язків фізичної особи, що становлять ії правоздатність як мюАини, набуваються та виконуються нею поза межами зАійснення госпоАарської Аіяльності, в поряаку реалізації нею ії цивільної Аієздатності, передбаченої Цивільним кодексом України, та регулюються ним. Останнє випливає зі змісту частини третьої статті 45 Господарського кодексу України, віАповіАно до якої щодо громаАян положення цього кодексу поширюються на ту частину їхньої Аіяльності, яка за своїм характером є піАприємницькою" [10].

Учасниками цивільних віАносин та суб'єктами права власності, на Аумку Аержавної фіскальної служби, є, зокрема, фізичні особи. Проте цКУ окремо не визначає такий суб'єкт права власності, як фізична особа - підприємець, набуття особою такого статусу Аозволяє ^ише зАійснювати господарську діяльність. Незалежно віА того, який статус у подальшому фізична особа обере Аля себе, в тому числі в разі прийняття рішення про зАійснення будь-якої Аіяльності (піАприємницької або незалежної професійної), суб'єктом права в^асності виступає саме фізична особа, а не піАприємець. Не передбачено і законодавчих підстав вважати майно, що знаходиться у приватній в^асності фізичної особи, основними засобами суб'єкта господарювання, якщо такий громадянин зареєструється підприємцем. Використання власного майна Аля зАійснення, зокрема, підпри- ємницької Аіяльності є оАним із напрямів розпоряАження майном фізичної особи [11].

Міністерство юстиції із цього приводу висловило свою позицію. Громадянин, який бажає реалізувати своє конституційне право на підприємницьку Аіяльність, після проходження віАповіАних реєстраційних та інших передбачених законодавством процедур за жодних умов не втрачає і не змінює свого статусу фізичної особи, якого він набув із моменту народження, а лише набуває до нього нової ознаки - "підприємець». Статус фізичної особи - підприємця - це юриАичний статус, який засвідчує право особи на заняття піАприємницькою Аіяльністю, а саме самостійною, ініціативною, систематичною, на власний ризик госпоАарською Аіяльністю, що зАійснюється суб'єктами господарювання (підприємцями) з метою Аосягнення економічних і соціальних результатів та одержання прибутку. При цьому юриАичний статус "фізична особа - підприємець" сам по собі не впливає і ніяким чином не обмежує будь-які правомочності особи, які випливають з ії цивільної право-, та Аієздатності. А^е в господарських віАносинах фізичні особи - піАприємці приймають участь перш за все як підприємці, а не як фізичні особи, та мише на підставі їх реєстрації і внесення відомостей про них до ЄАиного державного реєстру юридичних та фізичних осіб піАприємців [12].

Правовим статус особи називається тому, що становище особи в суспільстві визначається юридичними нормами, які опосередковують різносторонні зв'язКи АюАини із соціальним оточенням. У широкому розумінні слова піА правовим статусом особи розуміється юридично закріплене становище ^юАини у суспільстві, її права і свободи, обов'язки і відповідальність, встановлені законодавством і гарантовані державою. У вузькому розумінні категорія "правовий статус особи" характеризує обсяг прав і свобод, якими володіє ^юАина - суб'єкт права. Вони ж (права і свободи) складають основний сенс, яАро правового статусу [13, с. 480-481].

На Аумку Р. Майданика, якщо розглядати проблему розмежування статусу фізичної особи-піАприємця віА фізичної особи, яка неє підприємцем, то сенс Ааного відмежування необхідно вбачати в такому понятті, як ціль вчинення Ааного правочину. Тобто якщо виникає спір щодо суб'єкта, який придбав товар (тобто або як споживач, або як піАприємець), то його вирішення лежить у площині з'ясування характеру обліку, наступної поетапної реалізації отриманого чи передбаченого 


\section{2 回回回回回回回回回回回回回回回回回回回回 Випуск 33}

правового результату. Те саме необхідно робити і у скмаАніших ситуаціях, тобто піА час придбання товарів чи послуг, які наділені властивістю подвійного призначення, тобто як Аля власного споживання, так і для піАприємницької Аіяльності. Розмежування відбувається за такою ознакою, як систематичність піАприємницької Аіяльності, яку уподібнюють до постійності, регулярності, професійності роботи [14, с.14].

Правовим статусом, який піАтверАжує право особи на зайняття піАприємницькою Аіяльністю, $€$ саме статус фізичної особи - піАприємця, як зазначає О. Аем'яненко. Щодо самої господарської Аіяльності, то її основними ознаками можна виділити такі: регулярність, постійність, незалежність, ініціативність, власний ризик, а мета - отримання прибутку та очікуваних та бажаних результатів в економічній та соціальній сферах. Проте сам правовий статус фізичної особи - піАприємця Жодним чином не АискреАитує права, обов'язки, свободи чи інтереси особи, які випливають із їі право- та Аієздатності у цивільному праві $[15$, с. 157].

Висновки з провеАеного АосліАження. Ураховуючи зазначене, можна констатувати, що фізична особа набуває права інтелектуальної власності завжАи в якості виключно фізичної особи як такої. Пізніше, якщо особа хоче використовувати ці права у процесі господарської Аіяльності, правові механізми такого використання мають застосовуватись виходячи з мети такого використання. Саме мета використання буде впливати на правовий статус такого об'єкта інтелектуальної власності в якості об'єкта правовідносин і буде визначати зміст таких правовіАносин і право, яке Ао них застосовується. Правовий статус фізичної особи - піАприємця за своїм обсягом $є$ ширшим, ніж правовий статус фізичної особи, тому що вк^ючає в себе не лише останній, але і додаткові права та обов'язки особи у сфері піАприємницьких відносин. ВіАповіАно, у випаАку, якщо використання об'єкта інтелектуальної власності буде здійснюватись у рамках цих Аодаткових правомочностей, то таке використання буде потребувати віАповіАного нормативного забезпечення, а саме укладення договору між фізичною особою і фізичною особою-підприємцем про передання прав на об'єкт інтелектуальної власності.

Те ж саме відноситься і до об'єктів, що були створені особою, яка перебуває у трудових віА- носинах із фізичною особою - піАприємцем. Стаття 429 цК України каже, що майнові права інтелектуальної власності на об'єкт, створений у зв'язку з виконанням трудового Аоговору, належать працівникові, який створив цей об'єкт, та юридичній або фізичній особі, де або у якої він працює, спільно, якщо інше не встановлено договором. У такому випадку, якщо роботодавцем $€$ суб'єкт підприємницької Аіяльності, а найманий працівник отримує винагороду саме як працівник цього суб'єкта, права будуть належати або спільно автору і фізичній особі - піАприємцю, або сторонами такого Аоговору про належність прав будуть автор та фізична особа - піАприємець.

ЗгіАно зі статтею 1114 ЦК України факт переАання виключних майнових прав інтелектуальної власності, які відповіАно Ао законодавства $€$ чинними після їх державної реєстрації, піАлягає державній реєстрації. Стаття 463 ЦК встановлює, що суб'єктами права інтелектуальної власності на винахіА, корисну модель та промисловий зразок $€$ винахіАник, автор промислового зразка або інші особи, які набули прав на винахіА, корисну модель та промисловий зразок за Аоговором чи законом. Набуття права інтелектуальної власності таким суб'єктом, як фізична особа-піАприємець, та його суб'єктність у процесі реєстрації не передбачена. Те ж саме стосується і торговельних марок. Згідно зі статтею 493 ЦК суб'єктами права інтелектуальної власності на торговельну марку є фізичні та юридичні особи. Реєстрація прав на торговельну марку фізичною особою підприємцем як такою на своє ім'я законодавством не передбачена (хоча необхідно зазначити, що в Аеяких країнах застосовуються правові системи, Ае, навпаки, суб'єктом прав на торговельну марку може бути лише суб'єкт піАприємницької Аіяльності). Із цього випливає, що якщо особа, яка використовує такий об'єкт у піАприємницькій Аіяльності і хоче передати право власності на патент чи торговельну марку саме віА імені фізичної особи -пілприємця, то така передача не є можливою, зважаючи та те, що дана особа не є окремим суб'єктом права інтелектуальної власності. Це породжує певні незручності та різноманітні тлумачення правовідносин у зазначеній сфері. Ураховуючи зазначене, Аоцільно нормативно урегулювати зазначені правовіАносини шляхом внесення змін та Аоповнень Ао чинного законодавства. 


\section{NITEPATYPA:}

1. Цивільний кодекс України : Закон України від 16.01.2003 р. № 435-V. Київ : «Центр учбової літератури», 2018.296 с.

2. Господарський кодекс України : Закон України від 16.01.2003 р. № 436-IV. Київ : «Центр учбової літератури», 2018.150 с.

3. Конституція України : офіц. текст. Київ : КМ, 2013. 96 с.

4. Про авторське право і суміжні права : Закон України від 23.12.1993 р. № 3792-XII. Відомості Верховної Ради Украӥни (ВВР). 1994. № 13. Ст. 64 .

5. Про охорону прав на винаходи і корисні моделі : Закон України від 15.12. 1993 р. № 3687-ХІІ. Вiдомості Верховної Ради України (ВВР). 1994. № 7. Ст. 32.

6. Про розгляд звернення : Лист Дерєжавної фіскальної служби України від 28.04.2015 р. № 4000/Б/99-99-17-02-02-14. URL : http://search.ligazakon.ua/__doc2.nsf/link1/DFS00551.html.

7. Постанова Верховного Суду від 17 грудня 2018 року у справі № 810/1726/16. URL : http://www.reyestr.court.gov.ua/ Review/78626568.

8. Ухвала Львівського апеляційного адміністративного Суду від 31.08.2016 р. у справі № 876/2866/16. URL : http://search.ligazakon.ua/__doc2.nsf/link1/SO12310.html.

9. Постанова Київського окружного адміністративного від 02.11.2016 p. у справі 810/1726/16. URL: https://youcontrol.com.ua/ru/ catalog/court-document $/ 80891617 /$.

10. Постанова Вищого господарського суду від 14.09. 2006 р. у справі № 41/102. URL : https://ips.ligazakon.net/document/view/ SD062236.

11. Щодо використання майна фізичної особи - підприємця для здійснення підприємницької діяльності : Лист Державної фіскальної служби Українти від 08.09.2015 № 8523/B/99-99-17-02-02-14. URL : https://ips.ligazakon.net/document/view/ DFS00837?an=1.

12. Статус фізичної особи - підприємця: проблеми застосування законодавства : Розяснення Міністерства юстиції України від 14.01.2011p. URL : https://zakon.rada.gov.ua/laws/show/n0012323-11?lang=en.

13. Теория права и государства : учебник / под ред. В.В. Лазарева. Москва : Изд-во БЕК, 2001. 520 с.

14. Майданик Р. Проблеми правового становища фізичних осіб-підприємців. Юридична газета. 18.05.2006. № 9(69). С. 14-16.

15. Дем'яненко О.В. Статус фізичної особи-підприємця: проблеми застосування законодавства. Мала енциклопедія нотаріуса. 2011. № $1.200 \mathrm{c}$.

\section{Амитришин Володимир Степанович \\ НАБУТТЯ ТА РОЗПОРЯАЖАННЯ МАЙНОВИМИ ПРАВАМИ ІНТЕЛЕКТУАЛЬНОӤ ВААСНОСТІ ФІЗИЧНИМИ ОСОБАМИ - ПІАПРИЄМЦЯМИ}

АосліАжено особливості правового механізму набуття, розпоряджання і використання в господарській Аіяльності фізичними особами - підприємцями об'єктів інтелектуальної власності, особливості співвідношення правового статусу таких осіб та статусу фізичних осіб - авторів таких об'єктів і вплив їхнього правового статусу на правовідносини щодо прав інтелекттуальної власності. Проаналізована судова практика та розглянуті особливості окремих виАів Аоговорів щоАо переАання прав на торговельні марки та винаходи.

Киючові слова: розпоряАжання майновими правами інтелектуальної власності, суб'єкти права інтелектуальної власності, Аоговори щодо розпоряАжання правами інтелектуальної власності.

\section{Амитришин Владимир Степанович \\ ПРИОБРЕТЕНИЕ И РАСПОРЯЖЕНИЕ ИМУЩЕСТВЕННЫМИ ПРАВАМИ ИНТЕМЕКТУАЛЬНОЙ СОБСТВЕННО- СТИ ФИЗИЧЕСКИМИ АИЦАМИ - ПРЕАПРИНИМАТЕАЯМИ}

Исследованы особенности правового механизма приобретения, распоряжения и использования в хозяйственной Аеятельности физическими лицами - преАпринимателями объектов интемеектуальной собственности, особенности, соотношение правового статуса таких лиц и статуса физических лиц - авторов данных объектов и влияние их правового статуса на правоотношения относительно прав интелекттуальной собственности. Проанализирована судебная практика и рассмотренны особенности отАельных виАов Аоговоров о передаче прав на товарные знаки и изобретения.

Киючевые слова: распоряжение имущественными правами интемлектуальной собственности, субъектые права интемлектуальной собственности, Аоговоры о распоряжении правами интемлектуальной собственности.

\section{Dmutrushun Volodumur}

\section{ACQUIRING AND DISPOSING OF INTELLECTUAL PROPERTY RIGHTS BY NATURAL PERSONS-ENTREPRENEURS}

The legislation of Ukraine stipulates that the legal acts regulating the business activity of legal entities are applied to the entrepreneurial activity of natural persons. However, in practice, enforcement results in the emergence of controversial conclusions, since in some way the merger of the legal status of an individual with a legal status of a legal entity which, for their legal nature is different. This applies to the acquisition, state registration and disposal of property rights intelekual property. A citizen who wishes to exercise his right to entrepreneurial activity, after passing the corresponding registration and other procedures, under no circumstances loses and does not change his status of an individual who he has acquired from the moment of his birth, but only acquires a new sign - "entrepreneur". The legal status of the "individual entrepreneur" does not affect or limit the civil authority of the person, but in economic 


\section{4 回回回回回回回回回回回回回回回回回回回回回 Випуск 33}

relations, physical persons - entrepreneurs take part as entrepreneurs, and not as individuals. An individual acquires intellectual property rights always as solely an individual as such. If a person wants to use these rights in the process of economic activity, the legal mechanisms of such use should be applied based on the purpose of such use. It is the purpose of the use that will influence the legal status of such an object of intellectual property as the object of legal relationship and will determine the content of such legal relationships and the law applied to them The legal status of an individual - an entrepreneur, in its scope is wider than the legal status of physical the person, because it includes not only the last, but also additional rights and obligations of the person in the field of business relations. Accordingly, if the use of the object of intellectual property is carried out within the framework of these additional powers, such use will require appropriate regulatory support, namely, the conclusion of a contract between an individual and an individual entrepreneur on the transfer of rights to the object of intellectual property.

Key words: disposal of intellectual property rights, subjects of intellectual property rights, treaties of intellectual property rights disputes. 